\title{
Analytical modeling of mine water rebound: Three case studies in closed hard-coal mines in Germany
}

\author{
Dmytro Rudakov ${ }^{1 * \otimes(0)}$, Sebastian Westermann ${ }^{2 \otimes}$ \\ ${ }^{1}$ Dnipro University of Technology, Dnipro, 49005, Ukraine \\ ${ }^{2}$ Technische Hochschule Georg Agricola - University, Bochum, 44787, Germany \\ *Corresponding author: e-mail rudakov.d.v@nmu.one, tel. +380983779963
}

\begin{abstract}
Purpose. In this paper we present and validate an analytical model of water inflow and rising level in a flooded mine and examine the model robustness and sensitivity to variations of input data considering the examples of three closed hard-coal mines in Germany.

Methods. We used the analytical solution to a boundary value problem of radial ground water flow to the shaft, treated as a big well, and water balance relations for the series of successive stationary positions of a depression cone to simulate a mine water rebound in the mine taking into account vertical distribution of hydraulic conductivity, residual volume of underground workings, and natural pores.

Findings. The modeling demonstrated very good agreement with the measured data for all the studied mines. The maximum relative deviation for the mine water level during the measurement period did not exceed $2.1 \%$; the deviation for the inflow rate to a mine before its flooding did not exceed $0.8 \%$. Sensitivity analysis revealed the higher significance of the residual working volume and hydraulic conductivity for mine water rebound in the case of thick overburden and the growing significance of the infiltration rate and the flooded area size in the case of lower overburden thickness.

Originality. The developed analytical model allows realistic prediction of transient mine water rebound and inflow into a mine with layered heterogeneity of rocks, irregular form of the drained area, and with the inflow/outflow to a neighboring mine and the volume of voids as a distributed parameter without gridding the flow domain performed in numerical models.

Practical implications. The study demonstrated the advantages of analytical modeling as a tool for preliminary evaluation and prediction of flooding indicators and parameters of mined out disturbed rocks. In case of uncertain input data, modeling can be considered as an attractive alternative to usually applied numerical methods of modeling ground and mine water flow.
\end{abstract}

Keywords: mine flooding, mine water rebound, water level, inflow rate, analytical model, sensitivity analysis

\section{Introduction}

Extensive closure of hard-coal mines became a common trend in European countries with developed coal-mining industry in the last decades [1]-[3]. For example, Belgium closed its hard-coal mines in 1992; France did it by 2005, and the United Kingdom by 2016. The last two active hardcoal mines in Germany, Prosper-Haniel (Ruhr area) and Ibbenbüren (Tecklenburg region), have been closed in December 2018. In 1996 to 2013, 37 hard-coal mines were closed in Ukraine; according to long-term plans of the government, 29 mines should be closed in the country by 2050 .

Closure of the hard-coal mines made topical assessing the consequences of extensive and large-scale flooding [4] and sustainable resource utilization in post-mining period [5], [6]. This requires reliable prediction of mine water rebound, understanding the driven forces and key factors of this pro- cess, evaluation and refining flow parameters of disturbed rocks, which is of growing significance for water management in post-mining areas.

Most frequently mine water rebounds and inflows to the mines are simulated by numerical methods including finitedifference models [7]-[10], finite elements [11], [12], and volume balance models (like the box model [13]), which require, as a rule, many geological data for large mined out areas with quite heterogeneous rocks. In practice, studying the process of flooding the mines often runs across the scarcity and uncertainty of available data, which creates some difficulties to the application of widely used numerical models that need detailed parameter distributions on fine grids. At the same time, many data on spatial distributions of underground workings, especially those old and abandoned, are often either unavailable or uncertain. 
Under these limitations numerical models may lose their advantages in comparison to other more simple methods based on fundamental equations of water balance and seepage theory including analytical methods for modeling ground water flow [14], [15]. Moreover, in many studies, especially for preliminary assessments, a detailed account for geometry of underground voids is unnecessary except some specific cases like inter-mine hydraulic connections or drainage through underground galleries. But even this case can be simulated by analytical methods [15], [16].

In this paper we present an updated analytical model of inflow and rising mine water level in a mine being flooded that has been presented firstly in [15] and updated in [17]. The aim of this study is to demonstrate the possibilities of analytical modeling to evaluate and predict flooding indicators and parameters of mined out rocks. To perform a comprehensive study we examined the model robustness and sensitivity to key parameter variations on the examples of three flooded mines in Germany.

\section{Methods}

Below we describe an analytical model to analyze flooding a mine applicable under the following assumptions.

1. Generally we simulate an isolated mine; however, hydraulic connections to neighboring mines can be taken into account as additional terms in the water balance equation.

2 . The draining effect of a mine is simulated by a single well located in a geometrical center of the flow domain of circular form. Thereby we simulate radially symmetrical ground water flow to the shaft.

3 . Underground workings within the mine are interconnected, so if the mine water level rises at a rate up to a few $\mathrm{m} / \mathrm{d}$, horizontal disturbances of flow propagate much faster than vertical ones; hence, the mine water level rises simultaneously in all workings.

4. Rocks within the drained area have layered heterogeneity because of geological settings and mining operations.

5 . The residual volume of voids created by mining operations is uniformly distributed over each horizontal section within the mine.

6 . The ground water level on the outer boundary of the flow domain remains stable during flooding the mine.

Under these assumptions we can simulate radial ground water flow to the shaft with the time-dependent water level at the inner boundary (Fig. 1). The outer and inner boundaries of the flow domain in a planar view are replaced with two circles shown by dashed lines in Figure 2.

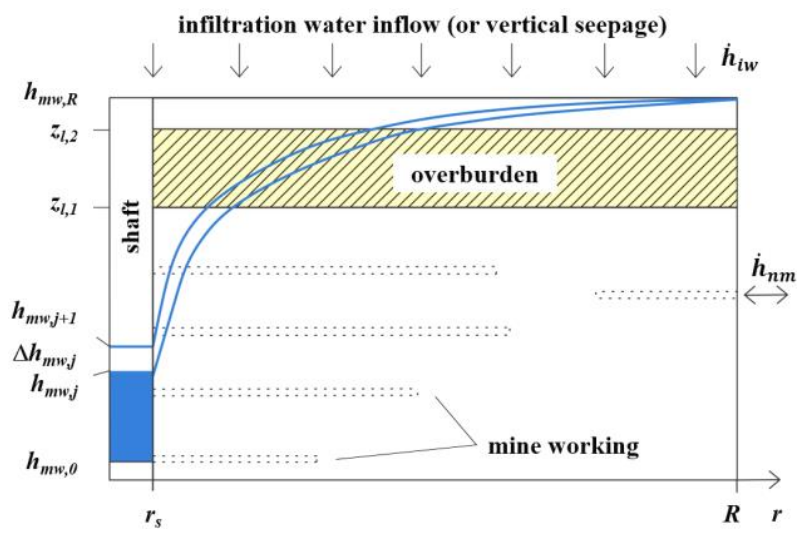

Figure 1. Vertical cross-section of the flow domain

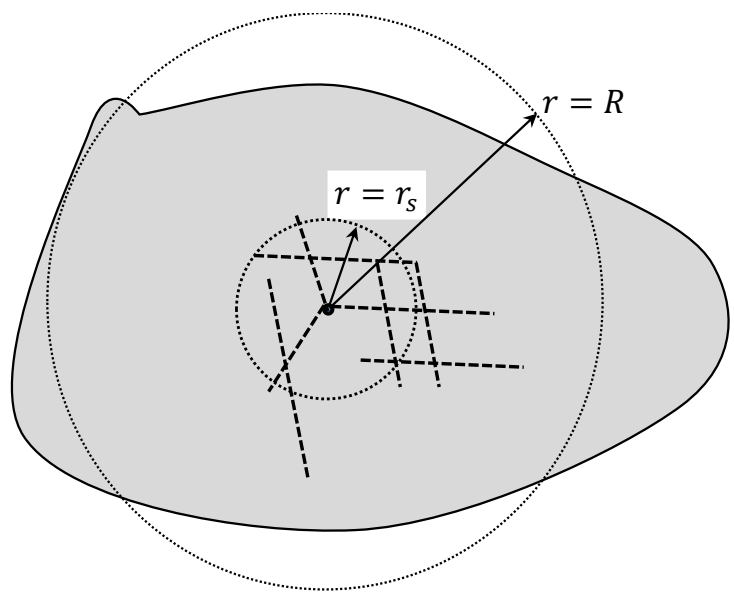

Figure 2. Approximation of flow domain boundaries. Bold lines are real contours of drained area boundaries, a point is a shaft, dot lines are the circle approximation of outer and inner boundaries, and dash lines are the contours of underground workings

To keep the maximum conformity between the real flow domain and the radial flow domain in the model we assume their areas are equal, with the shaft located in the geometrical center of the real domain. This can be acceptable under the assumption nr. 3 on interconnectivity of all underground workings even if there are irregularities of their locations. The evaluation of how shaft location influence the mine water rebound needs a special numerical study.

Ground water flow in a mine being flooded can be governed by the equation of radial flow to a single well, with the radial coordinate $r$ in the range $r_{s} \leq r \leq R$ :

$$
\frac{\partial\left(n_{e} \cdot h_{g w}\right)}{\partial t}=\frac{1}{r} \cdot \frac{\partial}{\partial r} \cdot\left(k_{f} \cdot h_{g w} \cdot r \cdot \frac{\partial h_{g w}}{\partial r}\right)+\dot{h}_{i w}+\dot{h}_{n m}
$$

where:

$n_{e}$-total effective porosity of rocks, dimensionless; $n_{e}=n_{e, n}+n_{e, a}$;

$n_{e, n}$ - natural floodable porosity, dimensionless;

$n_{e, a}$ - porosity of anthropogenic origin emerged as a result of mining operations, dimensionless;

$h_{g w}$ - ground water level, m SL;

$k_{f}$ - the hydraulic conductivity of rocks, $\mathrm{m} / \mathrm{d}$;

$r$ - the radial coordinate, $\mathrm{m}$;

$t$ - time, d;

$\dot{h}_{i w}$ - specific inflow rate of infiltration water to the flooded area, $\mathrm{m} / \mathrm{d}$;

$\dot{h}_{n m}-$ specific outflow rate (related to the flooded area) to neighbouring mines through connective galleries, $\mathrm{m} / \mathrm{d}$.

The ground water level $h_{g w}$ at the inner boundary $r=r_{s}$ changes in time simultaneously with the water level in the shaft and connected underground workings $h_{m w}$ :

$h_{g w}\left(r_{s}, t\right)=h_{m w}(t)$.

The hydraulic radius $r_{s}$ of the shaft can be evaluated as:

$r_{s}=\sqrt{\frac{A_{r w, a v}}{\pi}}$

where: 
$A_{r w, a v}$-average value of $A_{r w}(z)$ which is the horizontal area of the residual volume all underground workings at the elevation $z, \mathrm{~m}^{2}$. It is calculated as:

$$
A_{r w}(z)=\frac{V_{r w, 12}}{\left(z_{l, 2}-z_{l, 1}\right)},
$$

where:

$W_{r w, 12}(z)$ - volume of all underground workings in the layer limited by two horizontal sections $z=z_{l, 1}$ and $z=z_{l, 2}$ $\left(z_{l, 1} \leq z \leq z_{l, 2}\right), \mathrm{m}^{3}$.

The ground water head $h_{g w}$ on the outer boundary $r=R$ remains constant till the mine water level will completely rebound:

$h_{g w}(R, t)=h_{g w, R}$.

The radius $R$ of the flow domain is evaluated similar to Equation 3:

$R=\sqrt{\frac{A_{w c a}}{\pi}}$,

where:

$A_{w c a}$ - surface of the water catchment area drained by the mine, $\mathrm{m}^{2}$.

At first approximation this area can be represented as the combination of areas each drained by one of mining zones located at different depths, with each zone having its individual area of influence. As a rule, the lowest mining zone has the largest area of drainage influence. Within each zone we can discriminate two subzones; the first one envelops the outer horizontal contour of underground workings $\left(A_{e}\right)$, the second one is the ring-like area of drainage influence around the first zone $\left(A_{d}\right)$. Under this considerations the water catchment area of the mine can be evaluated as follows:

$A_{w c a}=A_{e}+A_{d}$,

where:

$A_{e}$ - area enclosing the horizontal projections of all underground excavations, $\mathrm{m}^{2}$;

$A_{d}$ - ring-like area drained by all underground workings, $\mathrm{m}^{2}$.

Converting the actual water catchment area to its circular equivalent of the same area (Fig. 3), taking into account Equation 7 and overlapping the different projections of mining zones located at different depths we can suggest:

$R_{e} \leq R \leq R_{e}+R_{d}$,

where:

$R_{e}$ - radius of a circle with the area equal to $A_{e}, \mathrm{~m}$;

$R_{e}$ - distance of drainage influence created by underground workings concentrated in the circle of the radius $R_{e}, \mathrm{~m}$.

Following Equation 6 and the assumption on circular form we can evaluate $R_{e}$ as:

$$
R_{e}=\sqrt{\frac{A_{e}}{\pi}} .
$$

The distance of drainage influence $R_{d}$ can be evaluated for each mining zone individually. However, regarding to uncertainties of the data on locations of underground workings and hydraulic connections, the optimal approach to evaluate $R_{d}$ is to calculate the draining influence for the whole mine.
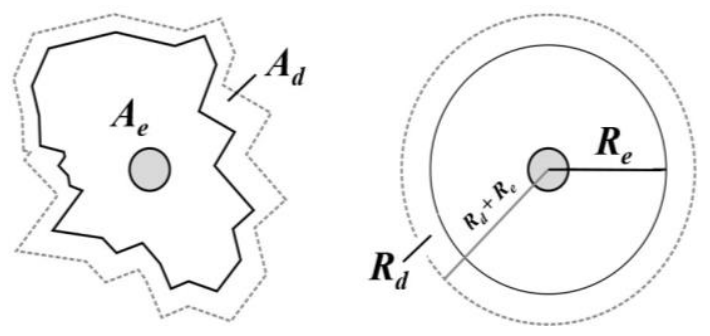

Figure 3. Conversion of the real area of drainage influence (left) into the model-confirming shape (right)

The well-known formulae of W. Sichardt and I. Kusakin [14] valid for a single well in homogenous aquifer hardly can be applied in case of mined out rocks. In contrast, the formulae proposed by Ye. Kerkis [18], [19] based on empirical data on mine drainage took into account the specifics of mined out rocks and are valid for late stages of mine drainage, which is in good agreement with the conditions of mines before their flooding. Regarding to overlapping of drainage influence zones the expected value of the radius $R$ can be calculated as:

$R=\sqrt{R_{e}+\frac{R_{d}}{2}}$,

where:

$R_{d}-$ is calculated by the formulae in [19] and refined in modeling of mine water rebound.

The term $\dot{h}_{n m}$ in Equation 1 can be calculated as:

$\dot{h}_{n m}=\frac{\dot{V}_{n m}}{A_{w c a}}$,

where:

$\dot{V}_{n m}$ - outflow rate to neighboring mines through connective galleries, $\mathrm{m}^{3} / \mathrm{d}$.

The boundary value problem defined by Equations 1, 2, and 5 is non-linear because rock transmissivity $T=k_{f} \cdot h_{t h, g w}$ depends on the groundwater-filled thickness $h_{t h, g w}$. Besides, the mine water level $h_{m w}(t)$ in Equation 2 depends on the inflows governed by ground water head gradient. For these reasons Equation 1 cannot be solved in an integral form, therefore we divide the total period of flooding $t_{f}$ on a number $N$ of equal time steps of duration $\Delta t$, so:

$\Delta t=\frac{t_{f}}{N}, t_{j}=j \Delta t, j=0, \ldots, N$

and the mine water level before flooding $h_{m w}(0)=h_{m w}, 0$.

Instead of solving the non-steady flow problem defined by Equations 1, 2, and 5 we solve a series of $N$ successive steady-state flow problems that differ each from other by the mine water level at the inner boundary $r=r_{s}$. For each $j$-th steady-state flow problem we calculate the water balance defined by the Equation:

$\dot{V}_{i n, j}-\dot{V}_{n m, j}=\frac{\Delta V_{\Sigma, j}}{\Delta t}$,

where:

$$
\dot{V}_{i n, j}=\dot{V}_{g w, j}+\dot{V}_{i w, j}, \mathrm{~m}^{3} / \mathrm{d} ;
$$


$\dot{V}_{g w, j}$ - the ground water inflow rate, $\mathrm{m}^{3} / \mathrm{d}$;

$\dot{V}_{i w, j}$ - infiltration water inflow rate (or vertical seepage rate), $\mathrm{m}^{3} / \mathrm{d}$;

$\dot{V}_{n m, j}$ - outflow rate to the neighboring mine(s); all are calculated for $j$-th time interval, $\mathrm{m}^{3} / \mathrm{d}$;

$\Delta V_{\Sigma, j}$ - change of water volume in the flow domain during the period $\Delta t, \mathrm{~m}^{3}$.

Ground water inflow rate to the mine is calculated based on Dupuit-Thiem formula for radial free surface flow [14]:

$$
\dot{V}_{g w, j}=\pi \cdot \bar{k}_{f, j} \cdot \frac{h_{g w, R}^{2}-h_{m w, j}^{2}}{\ln \left(\frac{R}{r_{s}}\right)},
$$

where:

$\bar{k}_{f, j}$ - average hydraulic conductivity of rocks within the minimum and maximum water levels during the time interval from $t_{j}$ to $t_{j+1}, \mathrm{~m} / \mathrm{d} ; \bar{k}_{f, j}$ can be evaluated by the formula:

$$
\bar{k}_{f, j}=\frac{1}{h_{g w, R}-h_{m w, j}} \int_{h_{m w, j}}^{h_{g w, R}} k_{f}(z) d z .
$$

Equation 13 enables taking into account layered heterogeneity of rocks due to geological settings and mining operations. Because of the raising mine water level the hydraulic conductivity $\bar{k}_{f, j}$ changes in time. The average natural porosity is calculated by analogy to Equation 13 .

Infiltration rate (or vertical seepage rate) can be calculated depending on the mine water level position over the bottom of the low-permeable layer $z l, 1$ :

$$
\dot{V}_{i w, j}=\left\{\begin{array}{ll}
k_{f, b} \cdot \pi \cdot R^{2}, & h_{m w} \leq z_{l, 1}, \\
\dot{h}_{i w}, & h_{m w} \geq z_{l, 1},
\end{array} .\right.
$$

where:

$k_{f, b}$-hydraulic conductivity of a low-permeable layer of the overburden, $\mathrm{m} / \mathrm{d}$.

Equation 14 means that the hydraulic conductivity of low-permeable layer controls the infiltration rate to underground workings until the mine water level is lower than the layer bottom. In practice $k_{f, b}$ and $\dot{h}_{i w}$ are quite often evaluated based on the water balance before flooding.

The outflow rate to neighboring mines $\dot{V}_{n m, j}$ is calculated for each case individually. In case if the hydraulic parameters of a connective inter-mine gallery are available, the method proposed and tested in [15] can be applied. If two mines, one is being flooded, the other is drained, are contacted through low-permeable barrier, the inflow rate to the drained mine can be calculated as shown below in the next section on the example of the colliery Königsborn.

The volume of water that flows in the mine $\Delta V_{\Sigma, j}$ during the time interval $\Delta t$ is distributed between residual man-made voids including underground workings of the volume $\Delta V_{r w, j}$ and floodable natural pores of the volume $\Delta n_{e, n, j}$ :

$$
\Delta V_{\Sigma, j}=\Delta V_{r w, j}+\Delta n_{e, n, j}
$$

Assuming the interconnectivity of all underground workings the volume $\Delta V_{r w, j}$ under relatively slow mine water rebound (i.e. small $\Delta h_{m w, j}$ during $\Delta t$ ) can be calculated as:

$$
\Delta V_{r w, j}=A_{r w, j} \cdot \Delta h_{m w, j}
$$

where:

$\Delta h_{m w, j}$-increment of the mine water level during the time interval $\Delta t, \mathrm{~m}$.

The volume $\Delta n_{e, n, j}$ is the volume of rocks limited by two curves in Figure 1 that are the surfaces of ground water head within the depression cone at the beginning and the end of the time interval $\Delta t$ multiplied by natural floodable porosity $n_{e, n}$. The value $\Delta n_{e, n, j}$ is calculated based on the ground water head for free surface flow at the discharge defined by Equation 10 .

Using Equations 15 and 16 we can rewrite Equation 11:

$$
\Delta V_{\Sigma, j}=A_{r w, j} \cdot \Delta h_{m w, j}+\dot{V}_{n m, j} \cdot \Delta t+\Delta V_{e, n, j}
$$

and calculate the rise of the mine water level during the time interval $\Delta t$ as follows:

$$
\Delta h_{m w, j}=\frac{\Delta V_{\Sigma, j}-\dot{V}_{n m, j} \cdot \Delta t-\Delta V_{e, n, j}}{A_{r w, j}} .
$$

Because of non-linearity of Equation $18\left(\Delta V_{e, n, j}\right.$ depends on the mine water level increment $\Delta h_{m w, j}$ ) we solve it numerically using an iterative procedure.

The mine water level at the moment $t_{j+1}$ is calculated by adding $\Delta h_{m w, j}$ to the mine water level at $t_{j}$ :

$$
h_{m w, j+1}=h_{m w, j}+\Delta h_{m w, j} \text {. }
$$

Equations 11-19 define the time-dependent cycle; after its completion we obtain the mine water level and water balance components for all moments $t_{j}$ during the flooding period.

To validate the model we have first to minimize the deviation $\Delta \dot{V}_{i w}$ between the calculated and measured initial inflow rate to the mine, which allows balancing inflows of ground water and infiltration water before flooding. Then we have to minimize the deviation $\Delta h_{m w}$ between the calculated and measured mine water level for the period $\left[0, t_{f}\right]$ :

$$
\Delta h_{m w}=\sqrt{\frac{1}{t_{f}} \int_{0}^{t_{f}}\left[h_{m w, c}(\tau)-h_{m w, m}(\tau)\right]^{2} d \tau},
$$

where:

$\Delta h_{m w, c}$ and $\Delta h_{m w, m}-$ measured and calculated mine water level, respectively, $\mathrm{m}$ SL.

The deviation in Equation 20 is the function depending on model parameters; those minimizing $\Delta h_{m w}$ can be interpreted as optimal model parameters for the measured mine water rebound. Regarding to low accuracy of geological data the task has to be evaluation of not only the optimal values of parameters but also their plausible intervals and model sensitivity to parameters variation.

The model sensitivity can be evaluated as the change of $\Delta h_{m w}$ caused by parameter variations. To evaluate the model sensitivity we used the relative deviation $\Delta h_{m w, r}$ (Equation 20):

$$
\Delta h_{m w, r}=\frac{\Delta h_{m w}}{h_{m w, d i f}} \cdot 100 \%
$$


where:

$\Delta h_{m w}$ - the deviation calculated by Equation 20, m;

$h_{m w, \text { dif }}=h_{m w, \max }-h_{m w, \min }, h_{m w, \text { dif }}$-difference between the highest $h_{m w, \max }$ and lowest $h_{m w, \text { min }}$ water levels during mine water rebound, $\mathrm{m}$.

In this paper we examine the influence of four parameters on model sensitivity that are the radius of the flooded area $R$, the specific inflow rate of infiltration water to the flooded area $\dot{h}_{i w}$, the volume of residual underground workings $V_{r w}$, and hydraulic conductivity $k_{f}$; the last two parameters depend on the vertical coordinate $z$. Model validation and parameter identification are performed in the following steps:

- evaluation of the guessed parameters $\left(R, \dot{h}_{i w}\right)$ for which the calculated initial inflow rate is the closest to the initial measured inflow rate;

- variation of the distributions of underground workings and hydraulic conductivity of rocks within estimated intervals in order to achieve the best coincidence with the measured mine water level;

- analysis of model sensitivity to parameter variations.

The algorithm has been implemented and tested by D.V. Rudakov in the Turbo-Pascal programming environment.

\section{Results and discussion}

The analytical model was used for modeling of mine water rebounds in three selected German mines (Fig. 4, Table 1) [20]. The collieries Westfalen (in Ahlen [North RhineWestphalia]) and Königsborn (in Unna [North RhineWestphalia]) are located in the south-east of the former Ruhr hard-coal mining area. The colliery Ibbenbüren is located in the Tecklenburg region (North Rhine-Westphalia). These three collieries have been closed and flooded for many years ago. They differ in their thickness of the overburden strata that consist of the less permeable strata of the Emscher formation (claystone) and the fissured and water-bearing strata of the Upper Cretaceous (marl limestone).

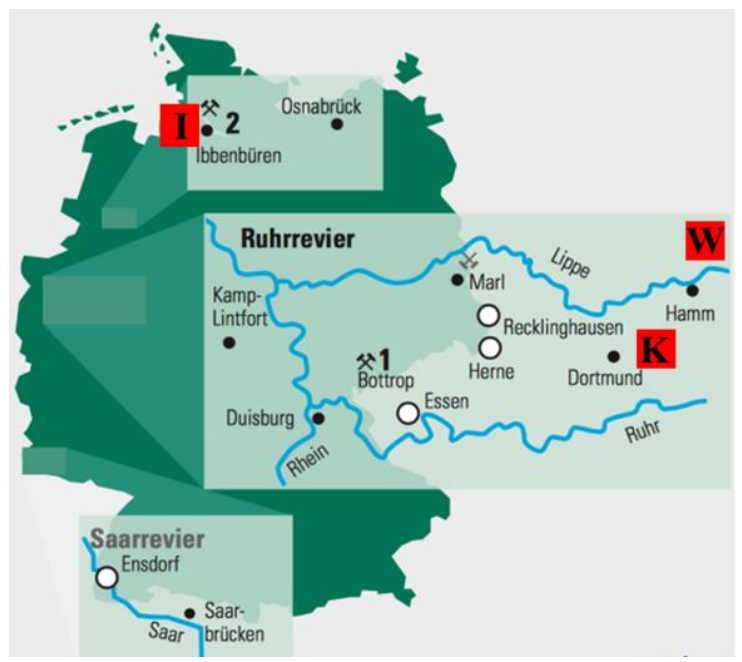

Figure 4. Location map of studied mines in Germany. Red squares: I-colliery Ibbenbüren; K-colliery Königsborn; W-colliery Westfalen. Numbers: last active hardcoal mines; 1-colliery Prosper-Haniel; 2-colliery Ibbenbüren) [21]

Vertical distribution of the residual volume of underground workings for the studies mines is shown in Figure 5.
Table 1. Basic data on flooding the selected mines

\begin{tabular}{lccc}
\hline \multicolumn{1}{c}{ Colliery } & Westfalen & Königsborn & Ibbenbüren \\
\hline $\begin{array}{l}\text { Day when } \\
\text { flooding began }\end{array}$ & 04.09 .2000 & 15.09 .1996 & 01.01 .1980 \\
\hline $\begin{array}{l}\text { Measured mine } \\
\text { water level, m SL }\end{array}$ & -1178 & -894 & -496 \\
\hline $\begin{array}{l}\text { Measured inflow rate } \\
\text { into the mine, } \mathrm{m}^{3} / \mathrm{d}\end{array}$ & 3600 & 4608 & 21744 \\
\hline $\begin{array}{l}\text { Day of last available } \\
\text { measurement }\end{array}$ & $28.11 .2016^{*}$ & $30.11 .2016^{*}$ & 28.12 .1982 \\
\hline $\begin{array}{l}\text { Measured mine water } \\
\text { level in the shaft, } \mathrm{m} \mathrm{SL}\end{array}$ & -431 & 301 & 66 \\
\hline $\begin{array}{l}\text { Area occupied } \\
\text { by the mine, km }\end{array}$ & 140 & 16 & 37 \\
\hline $\begin{array}{l}\text { Residual volume } \\
\text { reated by mining, } \mathrm{m}^{3}\end{array}$ & $1.02 \cdot 10^{7}$ & $1.01 \cdot 10^{7}$ & $5.54 \cdot 10^{6}$ \\
\hline
\end{tabular}

* flooding is still continuing

The colliery Westfalen has the biggest thickness of overburden rocks that varies between 795 and $889 \mathrm{~m}$. The thickness of the less permeable strata of the Emscher formation is between 475 and $600 \mathrm{~m}$.

Compared to the colliery Westfalen the colliery Königsborn has a lower overburden thickness. It varies between 180 and $300 \mathrm{~m}$. The average layer thickness of the fissured marl limestones is about $130 \mathrm{~m}$.

Due to close location of the shaft to low-permeable barrier to the neighboring colliery Heinrich Robert/Ost the area of colliery Königsborn is approximated as the half-circle. In calculations we took into account that the hydraulic conductivity of the Turonium + Cenomanium aquifer (Upper Cretaceous) is three orders higher than the hydraulic conductivity of the intact Carboniferous rocks.

Outflow rate to the neighboring mine at the mine water level $\Delta h_{m w, K b}$ in the colliery Königsborn below the bottom of the Turonium + Cenomanium aquifer at $z_{T+C, 1}=-217.8 \mathrm{~m}$ (position " 1 " in Figure 6) is calculated assuming unconfined ground water flow through a vertical wall of the length $4 \mathrm{~km}$ with the hydraulic conductivity of intact Carboniferous rocks of $10^{-5} \mathrm{~m} / \mathrm{d}$ and the mine water level in the colliery Heinrich Robert/Ost maintained at $-900 \mathrm{~m} \mathrm{SL}$ :

$\dot{V}_{n m, 1}=k_{f, b} \cdot \frac{h_{m w, K b}^{2}-h_{m w, H R O}^{2}}{2 l_{b}} \cdot l_{n m}$,

where:

$h_{m w, K b}$ and $h_{m w, H R O}$ - mine water level in the collieries Königsborn and Heinrich Robert/Ost, m SL;

$l_{b}-$ thickness of the low-permeable barrier between the mines, $\mathrm{m}$;

$l_{n m}-$ horizontal length of this barrier with the neighboring mine, $\mathrm{m}$;

$k_{f, b}-$ its hydraulic conductivity, m/d.

For the mine water level over the bottom of the Turonium + Cenomanium aquifer $\left(h_{m w, K b} \geq z_{T+C, 1}\right)$ and below than its top $\left(h_{m w, K b} \leq z_{T+C, 2}\right)$ at position " 2 " in Figure 6 the additional outflow rate from the colliery Königsborn can be calculated as:

$$
\dot{V}_{n m, 2}=\dot{V}_{n m, 1}+k_{f, T+C} \cdot \frac{h_{m w, K b}^{2}-z_{T+C, 1}^{2}}{2 l_{b}} \cdot l_{n m},
$$

where:

$k_{f, T+C}-$ hydraulic conductivity of the Turonium + Cenomanium aquifer, $\mathrm{m} / \mathrm{d}$. 
(a)

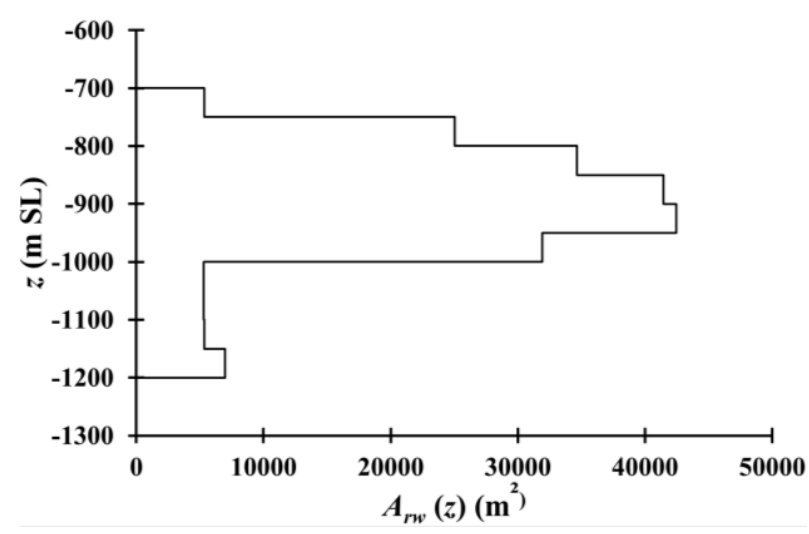

(b)

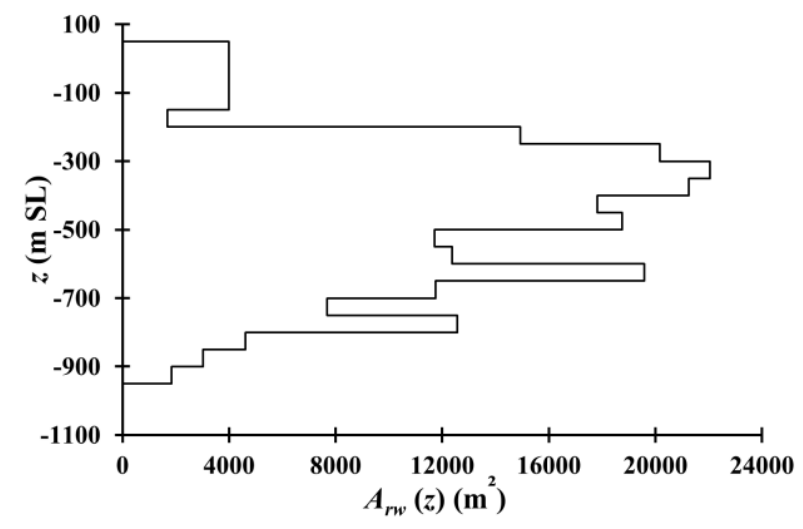

(c)

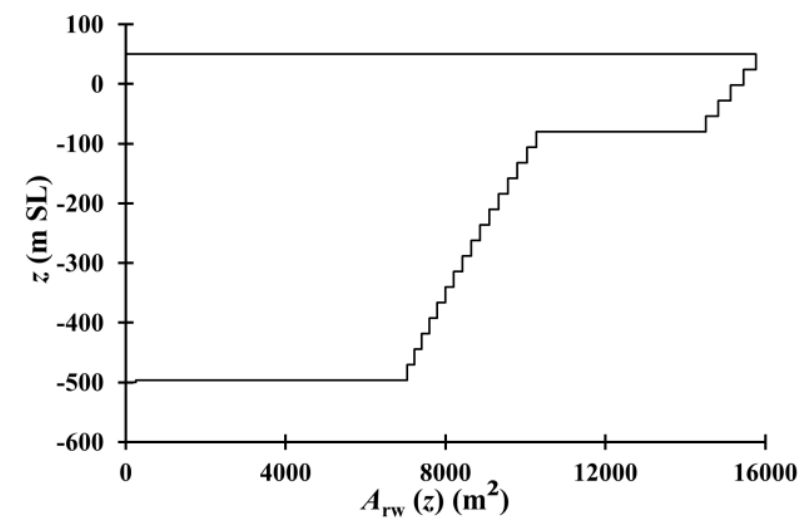

Figure 5. Vertical distribution of the residual volume of underground workings expressed as the surface of a horizontal crosssection of the mine workings $A_{r w}(z)$ : (a) colliery Westfalen; (b) colliery Königsborn; (c) colliery Ibbenbüren (Westfeld)

For the mine water level higher than the top of the Turonium + Cenomanium aquifer $z_{T+C, 2}\left(h_{m w, K b} \geq z_{T+C, 2}\right)$ the additional outflow rate from the colliery Königsborn is calculated as confined flow (position " 3 " in Figure 6) by Equation 22 replacing its second term in the right hand side with:

$$
k_{f, T+C} \cdot \frac{h_{m w, K b}-z_{T+C, 1}}{2} \cdot \frac{z_{T+C, 2}-z_{T+C, 1}}{l_{b}} l_{n m} .
$$

The colliery Ibbenbüren is divided into a western and eastern mining field. While the mining field "Westfeld" was flooded in the 1970s, hard-coal mining was carried out in the mining field "Ostfeld" until 2018.

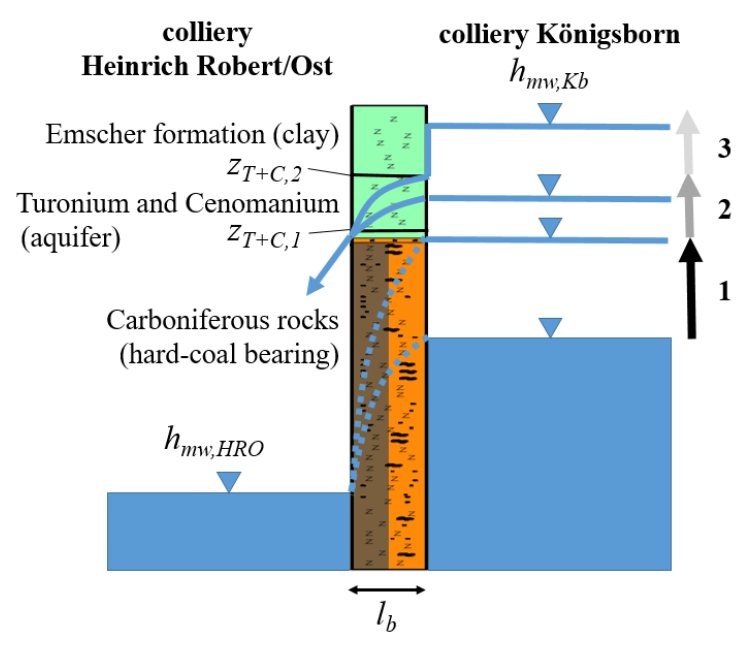

Figure 6. Sketch to calculate water flow through the lowpermeable barrier between two mines: 1, 2, 3-the water levels in the flooded mine and ground water heads in the low-permeable barrier. Notations see in text

The hard-coal deposit of the colliery Ibbenbüren (in the following, only the mining field "Westfeld" is considered) emerges morphologically from the surrounding area as a horst structure of the Carboniferous strata. Therefore, the hard coal-bearing strata are not covered by any overburden and crops out at the surface. Due to the missing of an overburden, the rainwater enters the mine directly.

Using the available data on geology, hydrogeology, and mining we evaluated the optimal model parameters (Table 2) that minimize the deviation $\Delta h_{m w}$ between measured and calculated mine water level in Equation 20.

Table 2. Parameters evaluated by inverse modeling

\begin{tabular}{cccc}
\hline Colliery & Westfalen & Königsborn & Ibbenbüren \\
\hline$R, \mathrm{~m}$ & 5700 & 3000 & 2800 \\
\hline$V_{r w}{ }^{*}, \mathrm{~m}^{3}$ & $1.02 \cdot 10^{7}$ & $1.01 \cdot 10^{7}$ & $5.5 \cdot 10^{6}$ \\
\hline$\dot{h}_{i w}, \mathrm{~m} / \mathrm{d}$ & $8.0 \cdot 10^{-6}$ & $1.39 \cdot 10^{-4}$ & $6.35 \cdot 10^{-4}$ \\
\hline$k_{f, a v}{ }^{*}, \mathrm{~m} / \mathrm{s}$ & $4.65 \cdot 10^{-8}$ & $8.32 \cdot 10^{-8}$ & $1.29 \cdot 10^{-9}$ \\
\hline
\end{tabular}

* total value distributed over the flooded thickness of rocks;

${ }^{* *}$ average value distributed over the flooded thickness of rocks.

The calculations demonstrated very good agreement with the measured data for all mines (Fig. 7, Table 3). The maximum relative deviation for the mine water level during the measurement period did not exceed $2.1 \%$; the deviation for the inflow rate to a mine before its flooding did not exceed $0.8 \%$.

Changing of the infiltration rate $\dot{h}_{i w}$ up to $\pm 10 \%$ does not deviate significantly the calculated values from those measured during the most part of flooding interval; changing of other parameters has similar effect.

The results of sensitivity analysis (Fig. 8) confirmed that the parameters in Table 3 are optimal for Equation 20 because they minimize the deviation $\Delta h_{m w}$ whereas changing all four varied parameters increase $\Delta h_{m w}$.

Table 3. Minimum relative deviations between measured and calculated data, \%

\begin{tabular}{cccc}
\hline Colliery & Westfalen & Königsborn & Ibbenbüren \\
\hline Mine water level & 2.1 & 1.2 & 1.0 \\
\hline Initial inflow rate & 0.8 & 0.1 & 0.1 \\
\hline
\end{tabular}


(a)

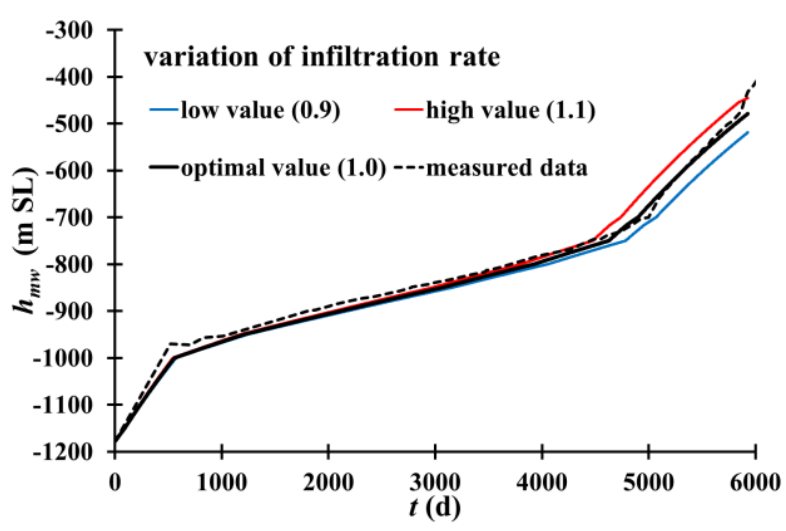

(b)

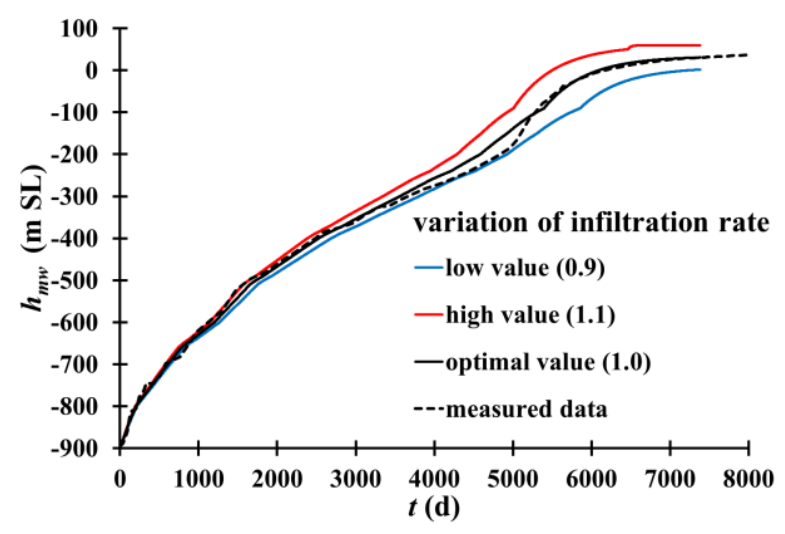

(c)

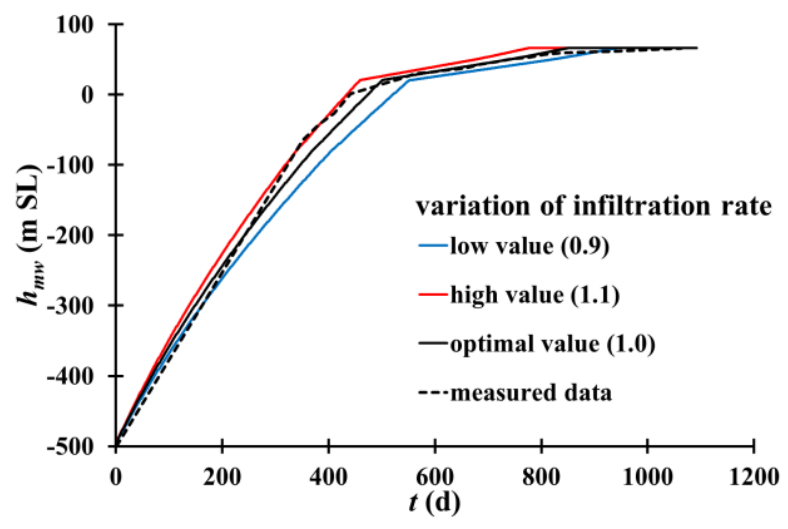

Figure 7. Mine water level $h_{m w}$ versus time $t$ in the collieries Westfalen (a), Königsborn (b), Ibbenbüren (c) at the parameters from Table 3 and different infiltration rates: $1.0 \varepsilon$ (black line); $0.9 \varepsilon$ (blue line); $1.1 \varepsilon$ (red line); black dots show the measured mine water level

For the colliery Westfalen with higher thickness of overburden the most influential parameters in terms of model sensitivity were found the residual volume of underground workings $V_{r w}$ and hydraulic permeability of rocks $k_{f}$, which means domination of the factors of deep water inflow. In contrast, for the collieries Königsborn and Ibbenbüren with lower and insignificant thickness of overburden the most influential parameters are the flooded area radius $R$ and the infiltration rate $\dot{h}_{i w}$; this is fully in line with growing significance of parameters that characterize vertical recharge of the flooded area. (a)

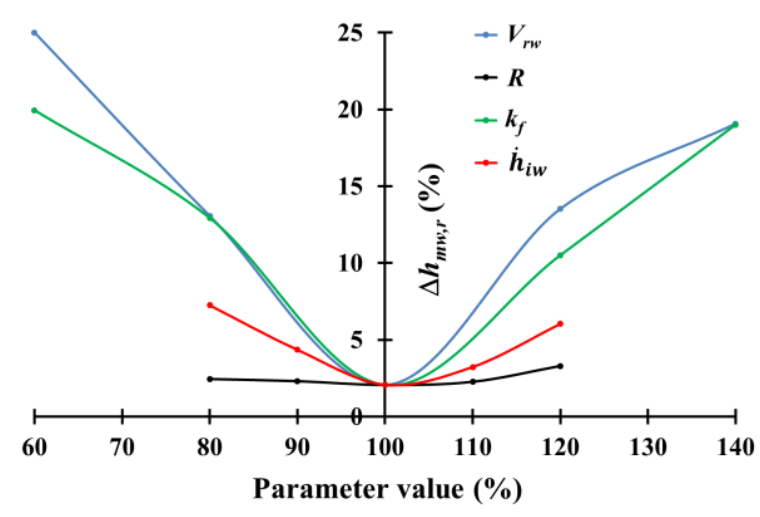

(b)

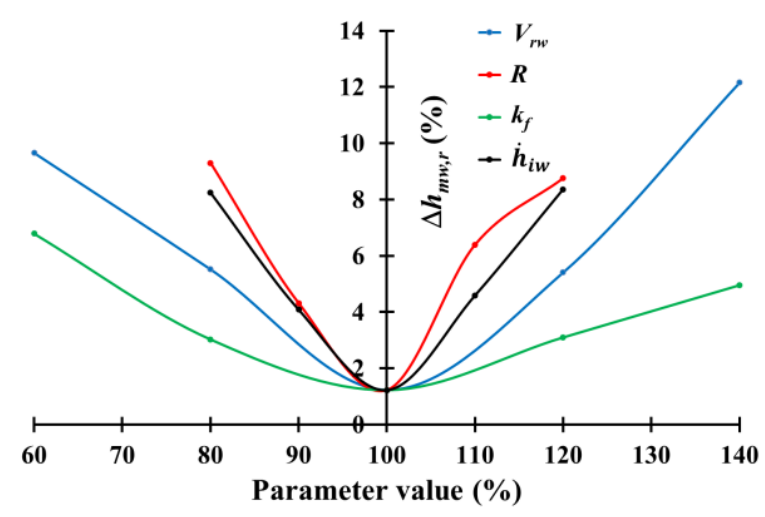

(c)

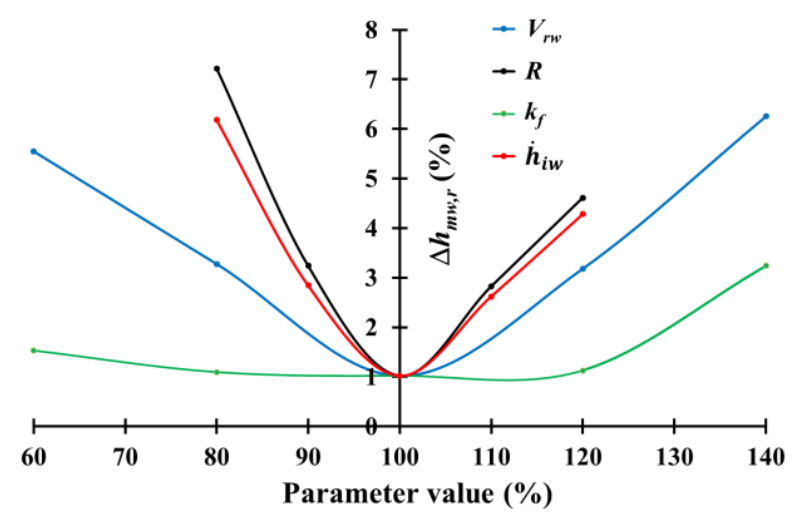

Figure 8. Relative deviation $\Delta h_{m w, r}$ between calculated and measured mine water level (Equation 21) versus change of input parameters for the collieries Westfalen (a); Königsborn (b); Ibbenbüren (c)

\section{Conclusions}

The mathematical model based on analytical relations of ground water flow theory and adapted to the availability of critical hydrogeological and mining parameters has been developed to simulate flooding the underground workings. The model has been tested for the examples of three closed hard-coal mines in Germany selected as case studies.

We used the analytical solution describing radial ground water flow to the shaft and water balance relations for the series of successive stationary depression cones. It takes into account layered heterogeneity of hydraulic conductivity, porosity, vertical distribution of underground workings, 
irregular form of the drained area, the inflow/outflow to neighboring mines without gridding the flow domain as it is performed in numerical models.

The modeling demonstrated very good agreement with the measured data for all studied mines. The maximum relative deviation for mine water level during the measurement period did not exceed $2.1 \%$ and the deviation for the inflow rate before flooding did not exceed $0.8 \%$. Sensitivity analysis revealed the higher role of the residual working volume and hydraulic conductivity for mine water rebound in case of thick overburden above underground workings like colliery Westfalen. Along with this, lowering thickness of overburden increases the influence the infiltration rate and the flooded area size in terms of model sensitivity for collieries Königsborn and Ibbenbüren.

The study demonstrated the advantages of analytical modeling as a tool for preliminary evaluation and prediction of flooding indicators and parameters of mined out disturbed rocks. In case of uncertain input data it can be considered as an attractive alternative to usually applied numerical methods of modeling ground and mine water flow.

\section{Acknowledgements}

We would like to thank RAG Aktiengesellschaft and DMT GmbH \& Co. KG (both Essen, Germany) for providing documents and data required to develop the analytical model.

\section{References}

[1] Mine closure and post-mining management. International state-the-art. (2008). Lisbon, Portugal: International Commission on Mine Closure. International Society for Rock Mechanics.

[2] Soni, A.K., \& Wolkersdorfer, C. (2016). Mine water: Policy perspective for improving water management in the mining environment with respect to developing economies. International Journal of Mining, Reclamation and Environment, 30(2), 115-127. https://doi.org/10.1080/17480930.2015.1011372

[3] Wolkersdorfer, C., \& Bowell, R. (2004). Contemporary reviews of mine water studies in Europe, Part 1. Mine Water and the Environment, 23(4), 162-182. https://doi.org/10.1007/s10230-004-0060-0

[4] Kessler, T., Mugova, E., Jasnowski-Peters, H., Rinder, T., Stemke, M., Wolkersdorfer, C., \& Schafmeister, M.-T. (2020). Grundwasser in ehemaligen deutschen Steinkohlenrevieren - ein wissenschaftlicher Blickwinkel auf Grubenflutungen. Grundwasser, 25(4), 259-272. https://doi.org/10.1007/s00767-020-00460-0

[5] LANUV NRW. (2018). Landesamt für Natur, Umwelt, und Verbraucherschutz nordrhein-westfahlen: Potenzialstudie warmes Grubenwasser-Fachbericht 90. Recklinghausen, Germany, 154 p.
[6] Loredo, C., Roqueñi, N., \& Ordóñez, A. (2016). Modelling flow and heat transfer in flooded mines for geotermal energy use: A review. International Journal of Coal Geology, (164), 115-122. https://doi.org/10.1016/j.coal.2016.04.013

[7] Banks, D. (2001). A variable-volume, head-dependent mine water filling model. Ground Water, 39(3), 362-365. https://doi.org/10.1111/j.1745-6584.2001.tb02319.x

[8] Sadovenko, I., Zagrytsenko, A., Podvigina, O., \& Derevyagina, N. (2016). Assessment of environmental and technical risks in the process of mining on the basis of numerical simulation of geofiltration. Mining of Mineral Deposits, 10(1), 37-43. https://doi.org/10.15407/mining10.01.037

[9] Sadovenko, I., Rudakov, D., \& Podvigina, O. (2010). Analysis of hydrogeodynamics in a mining region during exploitation till closure of coal mines. New Techniques and Technologies in Mining - Proceedings of the School of Underground Mining, 61-69. https://doi.org/10.1201/b11329-12

[10] Szczepiński, J. (2019). The significance of groundwater flow modeling study for simulation of opencast mine dewatering, flooding, and the environmental impact. Water, (11), 848. https://doi.org/10.3390/w11040848

[11] Quiros, A.G., \& Fernández-Álvarez, J.P. (2019). Conceptualization and finite element groundwater flow modeling of a flooded underground mine reservoir in the Asturian Coal Basin, Spain. Journal of Hydrology, (578), 124036. https://doi.org/10.1016/j.jhydrol.2019.124036

[12] Renz, A., Rühaak, W., Schätzl, P., \& Diersch, H.-J.G. (2009). Numerical modeling of geothermal use of mine water: Challenges and examples. Mine Water and the Environment, 28(1), 2-14. https://doi.org/10.1007/s10230-008-0063-3

[13] Eckart, M. (2011). BoxModel Concept: ReacFlow3D. Modelling of the flow of mine water and groundwater, mass and heat transport. Essen, Germany: DMT GmbH \& Co. KG, 34 p.

[14] Hölting, B., \& Coldewey, W.G. (2009). Einführung in die Allgemeine und Angewandte Hydrogeologie. Hamburg, Germany: Spektrum, 383 p.

[15] Sadovenko, I.O., \& Rudakov, D.V. (2010). Dynamics of mass transport with ground water flow during active and closing mining operations. Dnipropetrovsk, Ukraine: National Mining University, 216 p.

[16] Rudakov, D.V., Coldewey, W.G., \& Goerke-Mallet, P. (2014). Modeling the inflow and discharge from underground structures within the abandoned hardcoal mining area of Westfeld (Ibbenbüren) (pp. 699705). In: An Interdisciplinary Response to Mine Water Challenges. Sui, Sun, \& Wang (eds). Xuzhou, China: China University of Mining and Technology Press.

[17] Westermann, S., Rudakov, D., Reker, B., \& Melchers, C. (2019). Ein neuer Blick auf Grubenwasseranstiegsprozesse - ausgewählte Beispiele aus dem deutschen Steinkohlenbergbau. Markscheidewesen, 126(1), 30-38.

[18] Hydrogeologist's guide. Volume 1. (1967). Leningrad, Russia: Nedra, $592 \mathrm{p}$.

[19] Kerkis, Ye.Ye. (1955). Evaluation the radius of influence in inflow calculation. Moscow, Russia: Ugletechizdat, 100 p.

[20] Westermann, S. (2020). Modellbasierte Sensitivitätsanalyse systembestimmender Faktoren eines Grubenwasseranstiegs in Unteragebergwerken mittels statistischer Versuchsplanung. Thesis for a $\mathrm{PhD}$ in Technical Sciences Clausthal-Zellerfeld, Germany: Technische Universität Clausthal, $220 \mathrm{p}$.

[21] Gesamtverband Steinkohle e.V. (GvSt). (2017). Steinkohle 2017. Verantwortung für Generationen. Annual report, $67 \mathrm{p}$.

\section{Аналітичне моделювання відновлення рівня шахтних вод на прикладі трьох закритих кам'яновугільних шахтах у Німеччині}

\section{Д. Рудаков, С. Вестерман}

Мета. У роботі представлена та протестована аналітична модель припливу води та підйому його рівня в затоплюваній шахті. Досліджено стійкість моделі та іï чутливість до змін вихідних даних на прикладах трьох закритих шахт 3 видобутку кам'яного вугілля в Німеччині.

Методика. Використане аналітичне рішення крайової задачі радіального потоку підземних вод у шахтному стволі, який розглядається як великий колодязь, а також співвідношення водного балансу для послідовності стаціонарних положень конуса депресії при моделюванні відновлення рівня води в шахті з урахуванням вертикального розподілу коефіцієнту фільтрації, залишкового об'єму підземних гірничих виробок та природних пор.

Результати. Моделювання продемонструвало досить добру узгодженість для всіх досліджуваних шахт. Максимальне відносне відхилення рівня шахтних вод протягом періоду вимірювань не перевищило $2.1 \%$, а для припливу в шахту до $\dddot{11}$ затоплення - $0.8 \%$. Аналіз чутливості виявив більш високу значущість залишкового об'єму виробок та коефіцієнту фільтрації для відновлення рівня шахтних вод у випадку потужних перекриваючих порід та зростаючу значущість швидкості інфільтрації та розміру області затоплення у випадку меншої товщини цих порід.

Наукова новизна. Розроблена аналітична модель дозволяє реалістично прогнозувати нестаціонарне відновлення й приплив води в шахту з шаруватою неоднорідністю гірських порід, неправильною формою дренованої ділянки, припливом або відтоком до сусідньої шахти, а також об'ємом пустот як розподіленим параметром без сіткової дискретизації області фільтрації, виконуваної в чисельних моделях. 
Практична значимість. Дослідження продемонструвало переваги аналітичного моделювання як інструменту попереднього оцінювання та прогнозування показників затоплення та параметрів підробленого порушеного породного масиву. В разі невизначеності вхідних даних це можна розглядати як привабливу альтернативу зазвичай застосовуваним чисельним методам моделювання течій підземних та шахтних вод.

Ключові слова: затоплення шахт, відновлення рівня шахтних вод, рівень води, інтенсивність припливу, аналітична модель, аналіз чутливості

\section{Аналитическое моделирование восстановления уровня шахтных вод на примере трех закрытых каменноугольных шахт в Германии}

\section{Д. Рудаков, С. Вестерман}

Цель. В статье представлена и протестирована аналитическая модель притока воды и подъема ее уровня в затапливаемой шахте. Исследована надежность модели и ее чувствительность к изменениям исходных данных на примерах трех закрытых каменноугольных шахт в Германии.

Методика. Использовано аналитическое решение краевой задачи о радиальном потоке подземных вод в шахтном стволе, который рассматривается как большой колодец, а также соотношения водного баланса для серии последовательных стационарных положений депрессионного конуса при моделировании восстановления уровня воды в шахте с учетом вертикального распределения коэффициента фильтрации, остаточного объема подземных горных выработок и естественных пор.

Результаты. Моделирование продемонстрировало достаточно хорошую согласованность с измеренными данными для всех исследованных шахт. Максимальное относительное отклонение за период измерений уровня шахтных вод не превысило $2.1 \%$, а для притока в шахту до ее затопления - $0.8 \%$. Анализ чувствительности выявил более высокую значимость остаточного объема выработок и коэффициента фильтрации для восстановления уровня шахтных вод в случае мощных перекрывающих пород, и возрастающую значимость скорости инфильтрации и размера области затопления в случае меньшей толщины этих пород.

Научная новизна. Разработанная аналитическая модель позволяет реалистически прогнозировать нестационарное восстановление уровня шахтных вод и приток в шахту при слоистой неоднородности горных пород, неправильной формой дренируемой области, притоком или оттоком в соседнюю шахту, а также объемом пустот как распределенным параметром без сеточной дискретизации области фильтрации, выполняемой в численных моделях.

Практическая значимость. Исследование продемонстрировало преимущества аналитического моделирования как инструмента предварительной оценки и прогноза показателей и параметров затопления подработанного нарушенного породного массива. В случае неопределённостей исходных данных это можно рассматривать как привлекательную альтернативу обычно применяемым численным методам моделирования течений подземных и шахтных вод.

Ключевые слова: затопление шахты, восстановление уровня шахтных вод, уровень воды, интенсивность притока, аналитическая модель, анализ чувствительности 